\title{
Penerapan Hazard Analysis Critical Control Point (HACCP) terhadap penurunan bahaya mikrobiologis pada makanan khusus anak berbasis hewani di Rumah Sakit Umum Daerah Dr. Soedarso Pontianak
}

\author{
Widyana Lakshmi Puspita', Yenny Prawiningdyah², Fatma Zuhrotun Nisa ${ }^{3}$
}

\begin{abstract}
Background: One way to improve the quality of food provision in hospitals is by implementing hazard analysis critical control point (HACCP) in food processing.

Objective: The study aimed to identify the effect of HACCP implementation to the decrease of microbiological hazards of foods for children in particular at Nutrition Installation of Dr. Soedarso Hospital of Pontianak.

Methods: The study was a quasi experiment that use multiple time series design with intervention and cassation of intervention (ABA time series chain). Samples of the study were animal based food for children, cooking utensils used preparation, processing, and distribution of the food, the food providers and food processing containers. Samples were taken 3 times before and after the implementation of HACCP, each within a week duration.

Result: Average germ rate in foods and cooking utensils before implementation of HACCP was relatively high. After the implementation of HACCP there was a decrease. The result of statistical analysis showed that there were effects of HACCP implementation to the reduction of microbiological hazards in foods and cooking utensils $(p<0.05)$. Average score of knowledge on sanitation hygiene of food and practice of sanitation hygiene of foods after HACCP implementation increased. There was an increase of average score of knowledge on food sanitation hygiene and practice of food sanitation hygiene of HACCP implementation $(p<0.05)$. Average score of sanitation hygiene of food processing container after HACCP implementation increased.

Conclusion: The implementation of HACCP could reduce microbiological hazards (germ rate) of animal based special foods for children.
\end{abstract}

KEY WORDS HACCP, microbiological hazards, animal-based foods

\section{PENDAHULUAN}

Penyelenggaraan makanan terutama makanan khusus di rumah sakit harus optimal dan sesuai dengan mutu pelayanan standar kesehatan serta indikasi penyakit pasien (1). Penyelenggaraan makanan yang kurang memenuhi syarat kesehatan (tidak saniter dan higienis) selain memperpanjang proses perawatan, juga dapat menyebabkan timbulnya infeksi silang (cross infection) atau infeksi nosokomial (infeksi yang didapatkan di rumah sakit), yang di antaranya dapat melalui makanan $(2,3)$. Selain timbulnya infeksi nosokomial, penyelenggaraan makanan di rumah sakit yang tidak memenuhi standar kesehatan (tidak higienis) juga dapat menyebabkan keracunan makanan (4).

Data tentang terjadinya infeksi nosokomial khususnya yang berhubungan dengan penyelenggaraan makanan di rumah sakit belum tercatat, akan tetapi timbulnya infeksi nosokomial secara umum diketahui angkanya tergolong tinggi. Angka infeksi nosokomial di Jakarta sebesar $41,1 \%$, di Surabaya 73,3\% dan Yogyakarta kurang lebih 5,9\%.(5) Sedangkan di Pontianak meskipun angka kejadian infeksi nosokomial kecil namun angkanya cenderung naik, pada tahun 2003 sebesar 0,71\%, tahun 2004 sebesar 0,91\% dan tahun 2005 naik menjadi 1,83\% (6).
Hasil pemeriksaan angka kuman pada makanan dan peralatan makan yang diolah di Instalasi Gizi RSUD Dr. Soedarso diketahui tergolong tinggi (di atas nilai ambang batas $100 \mathrm{koloni} / \mathrm{g}$ makanan) yaitu untuk makanan pagi (bubur) rata-rata angka kumannya 4.896 koloni/gr dan nasi $1.949 \mathrm{koloni} / \mathrm{g}$, tempat bubur $383.506,75 \mathrm{koloni} / \mathrm{cm}^{2}$, tempat nasi $443.765 .50 \mathrm{koloni} / \mathrm{cm}^{2}$, sedangkan angka kuman pada sendok nasi dan bubur juga sama-sama tinggi yaitu $2.937,38 \mathrm{koloni} / \mathrm{cm}^{2}$ pada sendok nasi dan $2.937,38$ koloni/ $\mathrm{cm}^{2}$ pada sendok bubur (8).

Tingginya angka kuman pada makanan dan peralatan pengolahan, menunjukkan bahwa makanan dapat berperan sebagai agen penyakit. Hal ini disebabkan makanan dapat berfungsi sebagai media perkembangbiakan kuman, sarana penyebaran (vehicle) dan sebagai penyebab agen timbulnya kesakitan (7). Timbulnya infeksi

\footnotetext{
Instalasi Gizi RSUD Dr. Soedarso, Pontianak, e-mail: widyana.laksmi@ yahoo.com

2 Instalasi Gizi RSUP Sardjito, JI Kesehatan, Yogyakarta

3 Program Studi Gizi dan Kesehatan, Fakultas Kedokteran, UGM, JI Farmako, Sekip Utara, Yogyakarta 55281, e-mail: fatma_znisa@yahoo. com
} 
nosokomial dan keracunan pada pasien anak melalui makanan khusus sangat besar kemungkinannya. Hal ini disebabkan makanan yang diberikan untuk anak yang sedang dirawat, terdiri dari berbagai bentuk makanan yang mengandung protein hewani, sehingga memungkinkan bagi perkembangbiakan mikroorganisme patogen (8).

Penyelenggaraan makanan yang tidak saniter dan higienis akan menimbulkan gangguan kesehatan pada anak yang sedang dirawat, karena anak-anak sangat rentan tehadap penyakit. Untuk itu diperlukan upaya penyehatan atau pengendalian terhadap proses pengolahan makanan dengan mengendalikan faktor-faktor yang mempengaruhi pertumbuhan kuman pada makanan. Faktor-faktor tersebut berasal dari proses penanganan makanan, lingkungan dan orangnya sehingga makanan yang disajikan di rumah sakit tidak menjadi mata rantai penularan penyakit (9). Oleh karena itu diperlukan suatu pendekatan sistematis melalui upaya pengidentifikasian bahaya (hazard) baik fisik, kimiawi dan mikrobiologis pada proses pengolahan makanan dan melakukan pengendalian bahaya pada titik kritis dikenal dengan HACCP (Hazard Analysis Critical Control Point) (10). Dalam penyelenggaraan makanan di rumah sakit, HACCP adalah teknik yang dianjurkan untuk penyehatan makanan karena HACCP merupakan pendekatan paling efektif dari segi biaya untuk menjamin keamanan makanan di semua tahap penyediaannya dibandingkan dengan pengawasan tradisional atau dengan pengujian hasil akhir produk. HACCP juga merupakan jaminan mutu terhadap produk makanan yang diakui secara internasional $(11,12,4,13)$.

Sesuai dengan permasalahan tersebut, penelitian ini bertujuan untuk mengetahui pengaruh penerapan HACCP pada proses pengolahan makanan terhadap penurunan bahaya mikrobiologis pada makanan khusus anak berbasis hewani di Rumah Sakit Umum Daerah (RSUD) Dr. Soedarso Pontianak. Selain itu juga untuk mengetahui pengaruhnya terhadap perbedaan praktik higiene sanitasi makanan, pengetahuan higiene sanitasi makanan, kebersihan peralatan masak dan higiene sanitasi lingkungan tempat pengolahan makanan sebelum dan sesudah penerapan HACCP pada makanan khusus anak berbasis hewani.

\section{BAHAN DAN METODE}

Jenis penelitian ini adalah eksperimen semu (quasi experiment) dengan rancangan berkala (time series) majemuk dengan pemberian dan penghentian intervensi rangkaian berkala "ABA" (14).

Penelitian ini dilakukan di Instalasi Gizi RSUD Dr. Soedarso Pontianak pada bulan Oktober 2007-Februari 2008. Populasi penelitian ini meliputi seluruh makanan khusus anak yang diolah, tenaga penjamah makanan, peralatan, tempat dan sarana kesehatan lingkungan pada ruang pengolahan makanan di instalasi gizi. Sampel dalam penelitian ini adalah makanan khusus anak berbasis hewani, sedangkan penjamah makanan adalah tenaga yang khusus menyiapkan, memasak dan mengatur distribusi makanan khusus anak. Peralatan adalah alatalat yang digunakan untuk persiapan, pengolahan dan distribusi makanan khusus anak. Tempat yaitu lokasi yang dijadikan sebagai tempat persiapan, pengolahan dan distribusi makanan.

Sampel yang diambil untuk tenaga persiapan, pengolahan dan distribusi makanan khusus pada pasien anak sebanyak 6 orang. Makanan khusus anak yang dijadikan sampel yaitu terbuat dari jenis lauk hewani. Peralatan masak yang dijadikan sampel sebanyak 13 buah. Sampel diambil tiga kali sebelum dan sesudah penerapan HACCP, dengan rentang waktu masing-masing satu minggu.

Keadaan higiene sanitasi lingkungan tempat pengolahan makanan adalah keadaan kebersihan lokasi yang dijadikan sebagai tempat persiapan, pengolahan dan distribusi makanan yang meliputi keadaan kebersihan lokasi secara umum (bangunan), penghawaan, pencahayaan, kebersihan lantai, dinding, langit-langit, penyediaan air bersih, tempat pengumpulan sampah, toilet, sarana pengendalian lalat/tikus dan saluran pembuangan air limbah. Data tersebut diambil tiga kali sebelum dan tiga kali sesudah penerapan HACCP, dengan rentang waktu masing-masing satu minggu.

Variabel independen penelitian ini adalah penerapan HACCP, sedangkan variabel dependen terdiri dari bahaya mikrobiologis pada makanan khusus anak, praktik higiene sanitasi makanan, pengetahuan penjamah makanan, kebersihan peralatan masak dan higiene sanitasi lingkungan tempat pengolahan makanan pasien.

Penelitian ini menggunakan data primer melalui wawancara, observasi langsung dan pemeriksaan laboratorium. Data praktik higiene sanitasi makanan dan keadaan sanitasi kesehatan lingkungan dikumpulkan dengan observasi langsung menggunakan check list (daftar tilik). Data pengetahuan dilakukan melalui wawancara dengan kuesioner. Data kebersihan peralatan dan mikrobiologi pada makanan ditentukan dengan cara pengukuran angka kuman. Data sekunder diambil dari ruangan dan bagian administrasi rumah sakit, instalasi gizi serta rekam medik.

Pelaksanaan penelitian ini melalui beberapa tahap yaitu tahap persiapan dan tahap penelitian. Tahap persiapan dimulai dengan menyusun instrumen penelitian serta melakukan uji coba kuisioner dan daftar tilik. Selanjutnya menyempurnakan dokumen pemantauan penerapan HACCP dan mengajukan izin penelitian ke rumah sakit. Tahap penelitian yaitu pengambilan data sebelum penerapan HACCP hingga evaluasi setelah penerapan HACCP termasuk pengukuran mikrobiologis pada makanan. 
Penerapan HACCP dimulai dengan sosialisasi kepada tenaga terkait di instalasi gizi, untuk selanjutnya diberikan penyuluhan mengenai penerapan HACCP dan higiene sanitasi makanan. Penyuluhan disampaikan oleh tenaga pengajar dari Politeknik Kesehatan Depkes Pontianak yang telah mendapatkan sertifikat di bidang HACCP. Setelah itu juga dilakukan pemasangan petunjuk mengenai cara sehat dan aman dalam pengolahan makanan.

Selanjutnya dibentuk tim yang akan mengawasi pelaksanaan penerapan HACCP yang terdiri dari ahli gizi dan tenaga sanitasi. Ahli gizi akan mengawasi pelaksanaan HACCP. Tenaga sanitasi akan mengawasi praktik higiene sanitasi makanan, kebersihan peralatan dan higiene sanitasi lingkungan.

Kegiatan ini dimulai dengan membuat keterangan tentang makanan khusus anak yang berbasis hewani. Selanjutnya diagram alir disusun mulai dari persiapan bahan sampai distribusi makanan. Kegiatan berikutnya, yaitu menerapkan prinsip-prinsip dalam HACCP. Pengambilan data dilakukan kembali setelah tiga bulan penerapan HACCP.

Data diolah dan dianalisis secara deskriptif dan analitik. Analisis deskriptif dilakukan untuk memberikan gambaran karakteristik dalam bentuk tabel distribusi frekuensi. Selanjutnya dibandingkan dengan standar kualitas yang telah ditetapkan oleh Depkes dalam penyelenggaraan penyehatan makanan di rumah sakit. Analisis tersebut digunakan untuk menggambarkan keadaan praktik higiene sanitasi makanan, penerapan HACCP, pengetahuan, kebersihan peralatan, higiene sanitasi lingkungan tempat pengolahan makanan dan bahaya mikrobiologis pada makanan khusus anak.

Analisis analitik digunakan untuk mengetahui perbedaan antarvariabel sebelum dan sesudah penerapan HACCP pada makanan khusus anak, dengan uji statistik beda mean menggunakan uji $t$ berpasangan. Tingkat signifikansi yang digunakan adalah 95\% ( $\alpha=5 \%$ ). Penolakan Ho ditentukan jika nilai $p \leq 0,05$ dan penerimaan Ho jika nilai $p>0,05(15,16)$.

\section{HASIL DAN BAHASAN}

\section{Bahaya mikrobiologis pada makanan dan peralatan masak sebelum dan sesudah penerapan HACCP}

Bahaya mikrobiologis pada makanan sebelum dan sesudah penerapan HACCP Tabel 1 merupakan hasil pemeriksaan jumlah angka kuman, pada makanan pasien di rumah sakit Dr. Soedarso Pontianak, menunjukkan adanya kecenderungan penurunan jumlah angka kuman sesudah penerapan HACCP selama tiga bulan.

Rata-rata jumlah angka kuman pada makanan sebelum penerapan HACCP tergolong tinggi yaitu 763,70 koloni/g dan setelah penerapan HACCP menurun menjadi 248,15 koloni/g. Makanan yang memenuhi persyaratan angka kuman sebelum penerapan HACCP juga rendah 44,4\% (4 sampel) dibandingkan dengan sesudah penerapan HACCP 66,67\% (6 sampel). Hal ini menunjukkan bahwa penerapan HACCP dapat menurunkan jumlah angka kuman pada makanan.

Tabel 1. Angka kuman pada makanan berbasis hewani sebelum dan sesudah penerapan HACCP

\begin{tabular}{ccc}
\hline \multirow{2}{*}{$\begin{array}{c}\text { Pemeriksaan } \\
\text { makanan }\end{array}$} & \multicolumn{2}{c}{ Angka kuman (koloni/g) } \\
\cline { 2 - 3 } & $\begin{array}{c}\text { Sebelum } \\
\text { penerapan HACCP }\end{array}$ & $\begin{array}{c}\text { Sesudah penerapan } \\
\text { HACCP }\end{array}$ \\
\hline Telur & $2.483,33$ & 300,00 \\
& 0,00 & 0,37 \\
Ikan & $1.400,00$ & 0,00 \\
& 0.00 & 0,00 \\
& 996,67 & 0,00 \\
Ayam & 0,00 & 966,67 \\
& 996,67 & 0,00 \\
& 996,67 & 0,00 \\
Rata-rata & 0,00 & 966,67 \\
\hline
\end{tabular}

Keterangan:

$t=3,356 \quad{ }^{*} p=0,003$

* Bermakna ( $p<0,05$; uji t berpasangan)

Analisis statistik dengan uji test menunjukkan adanya perbedaan yang signifikan jumlah angka kuman pada makanan sebelum dan sesudah penerapan HACCP ( $p=$ $0,003)$. Sehingga dapat disimpulkan bahwa penerapan HACCP dapat menurunkan jumlah angka kuman pada makanan khusus anak berbasis hewani.

Hasil penelitian yang serupa dilakukan Rumah Sakit Quezone City, Philipines menunjukkan bahwa aplikasi HACCP terhadap formula makanan blender yang diobservasi secara terus menerus dapat menurunkan kontaminasi mikroorganisme (kuman patogen). Sebaliknya aplikasi HACCP yang tidak diobservasi secara terus-menerus menaikkan angka cemaran mikroorganisme (17).

Penelitian lain tentang implementasi HACCP terhadap kontaminasi bahaya mikrobiologis, seperti E.coli, Pseudomonas sp. dan Listeria sp. pada makanan enteral (enteral feeding) di Rumah Sakit Costa Rica pada tahap persiapan dan penangan makanan enteral (enteral tube feeding) dapat menurunkan pertumbuhan mikroorganisme patogen (18).

Penelitian sejenis yang dilakukan di Rumah Sakit Florianopolis, Santa Catarina, Brasil, menemukan bahwa aplikasi HACCP secara sistematis pada tahap persiapan, pengolahan, penyimpanan dan distribusi makanan pasien enteral (enteral tube feeding), menunjukkan penurunan kontaminasi sejumlah angka kuman secara efektif antara sebelum (105 jumlah koloni/mL) dan sesudah penerapan HACCP (<102 jumlah koloni/mL) (19). 
Berdasarkan hasil penelitian ini dan beberapa penelitian lain yang sejenis, disimpulkan bahwa salah satu upaya untuk menurunkan jumlah angka kuman, khususnya kuman patogen pada makanan pasien yang berbasis hewani, diperlukan penerapan HACCP.

Pelaksanaan implementasi ini harus dilakukan melalui observasi secara kontinyu baik harian, mingguan, maupun bulanan, penyuluhan dan pemberian contoh atau petunjuk operasional cara kerja yang aman dan sehat, secara rutin dan terus menerus. Dengan cara ini diharapkan faktor yang mempengaruhi penerapan HACCP pada makanan pasien seperti tingkat pengetahuan dan praktik higiene sanitasi makanan petugas (food handler), penyediaan sarana higiene sanitasi dan pelaksanaan penyehatan lingkungan tempat pengolahan makanan pasien di rumah sakit dapat ditingkatkan.

\section{Bahaya mikrobiologis pada peralatan masak sebelum dan sesudah penerapan HACCP}

Tabel 2 menunjukkan bahwa rata-rata jumlah angka kuman pada peralatan masak sebelum penerapan HACCP tergolong tinggi (>100 koloni/cm²). Sesudah penerapan HACCP hasil pemeriksaan bahaya mikrobiologis (jumlah angka kuman) pada peralatan yang digunakan pada proses persiapan, pengolahan dan distribusi menunjukkan penurunan. Sebelum penerapan HACCP rata-rata jumlah kuman pada peralatan $1.659,89 \mathrm{koloni} / \mathrm{cm}^{2}$ dan sesudah penerapan HACCP turun menjadi 172,82 koloni/ $\mathrm{cm}^{2}$.

Sesudah penerapan HACCP masih terdapat angka kuman yang tinggi pada beberapa alat persiapan (blender), pengolahan (sutil) dan distribusi (wadah 2, penjepit 1 dan
2). Hal ini disebabkan karena penggunaan sabun untuk pencucian peralatan tidak mengandung bakterisida, sabun yang digunakan berupa sabun colek biasa dan tidak tersedianya sarana air panas untuk proses pembersihan lebih lanjut.

Untuk mendapatkan hasil akhir cucian yang sehat dan aman diperlukan tahapan-tahapan pencucian yang benar seperti scraping (membuang sisa kotoran), flusing (merendam dalam air), washing (mencuci dengan deterjen), rinsing (membilas dengan air bersih), sanitizing/ desinfection (membebashamakan) dengan merendam dalam air panas pada suhu $80^{\circ} \mathrm{C}$ selama dua menit atau pada suhu $100^{\circ} \mathrm{C}$ selama satu menit, tahap terakhir yaitu toweling (mengeringkan) dengan lap kering dan bersih (20).

Analisis statistik dengan $t$ test pada Tabel 2 menunjukkan adanya perbedaan yang signifikan ratarata jumlah angka kuman pada peralatan makanan antara sebelum dengan sesudah penerapan $\operatorname{HACCP}(p=0,000)$. Dengan kata lain dapat disimpulkan bahwa penerapan HACCP dapat menurunkan jumlah angka kuman pada peralatan yang digunakan untuk persiapan, pengolahan dan distribusi makanan pasien.

Pentingnya pemeriksaan bahaya mikrobiologis (angka kuman) pada peralatan baik yang digunakan untuk persiapan, pengolahan dan distribusi secara berkala berkaitan dengan dampak pencemaran peralatan terhadap bahaya mikrobiologis pada makanan pasien. Peralatan yang tidak saniter atau tercemar oleh kuman patogen akan berpengaruh terhadap kualitas mikrobiologis (terjadinya pencemaran) pada makanan pasien (20). Berdasarkan hasil analisis statistik diketahui ada hubungan

Tabel 2. Rata-rata angka kuman pada peralatan persiapan, pengolahan dan distribusi makanan sebelum dan sesudah penerapan HACCP

\begin{tabular}{clrr}
\hline \multirow{2}{*}{ Peralatan } & \multicolumn{2}{c}{ Angka kuman } & (koloni/cm ${ }^{2}$ ) \\
\cline { 3 - 4 } & & $\begin{array}{c}\text { Sebelum penerapan } \\
\text { HACCP }\end{array}$ & $\begin{array}{c}\text { Sesudah penerapan } \\
\text { HACCP }\end{array}$ \\
\hline Persiapan & Wadah 1 & 794,53 & 8,75 \\
& Wadah 2 & 794,53 & 8,75 \\
& Pisau & $1.793,46$ & 35,53 \\
Pengolahan & Blender & $2.895,02$ & 692,38 \\
& Wadah & $2.899,21$ & 0,34 \\
& Kukusan & $1.304,82$ & 11,85 \\
\multirow{5}{*}{ Distribusi } & Sutil & $2.904,99$ & $1.013,48$ \\
& Wajan & 52,02 & 0.21 \\
& Wadah 1 & $2.058,49$ & 0.33 \\
& Wadah 2 & 311,47 & 284,14 \\
& Wadah 3 & $1.336,67$ & 1,28 \\
Rata-rata & Penjepit1 & $3.553,68$ & 94,79 \\
& Penjepit2 & 879,63 & 94,79 \\
& & $1.659,89$ & 172,82 \\
\hline
\end{tabular}

Keterangan:

$t=4,596 \quad$ nilai ${ }^{*} p=0,000$

* Bermakna ( $p<0.05$; uji t berpasangan) 
Tabel 3. Pengetahuan higiene sanitasi makanan penjamah sebelum dan sesudah penerapan HACCP

\begin{tabular}{ccccccccc}
\hline \multirow{2}{*}{ Subjek } & \multicolumn{7}{c}{ Pengetahuan higiene sanitasi makanan } \\
\cline { 2 - 9 } & \multicolumn{7}{c}{ Sebelum penerapan HACCP } & \multicolumn{5}{c}{ Sesudah penerapan HACCP } \\
\cline { 2 - 9 } & $\mathbf{1}$ & $\mathbf{2}$ & $\mathbf{3}$ & Rata-rata & $\mathbf{1}$ & $\mathbf{2}$ & $\mathbf{3}$ & Rata-rata \\
\hline 1 & 80 & 73 & 80 & 77,7 & 86 & 86 & 93 & 88,3 \\
2 & 93 & 93 & 93 & 93,0 & 93 & 93 & 93 & 93,0 \\
3 & 86 & 80 & 86 & 84,0 & 93 & 86 & 93 & 88,7 \\
4 & 80 & 66 & 73 & 74,0 & 86 & 80 & 93 & 86,3 \\
5 & 60 & 66 & 66 & 64,0 & 93 & 93 & 93 & 93,0 \\
6 & 80 & 73 & 80 & 77,7 & 93 & 93 & 93 & 93,0 \\
Rata-rata & 79,8 & 76,3 & 79,7 & 78,7 & 90,1 & 89,7 & 91,8 & 90,4 \\
\hline
\end{tabular}

Keterangan:

$t=2,888, \quad * p=0,016$

* Bermakna ( $p<0,05$, uji t berpasangan)

$1,2,3$ = pengambilan sampel dalam interval minggu

yang bermakna antara tingginya jumlah angka kuman pada peralatan dengan besarnya angka kuman (bahaya mikrobiologis) pada makanan pasien $(p=0,019)$.

\section{Pengetahuan dan praktik higiene sanitasi makanan sebelum dan sesudah penerapan HACCP}

Pengetahuan penjamah sebelum dan sesudah penerapan HACCP Berdasarkan Tabel 3 dapat diketahui bahwa rata-rata nilai pengetahuan selama tiga kali berturut-turut untuk seluruh subjek adalah 78,7 . Nilai ini menggambarkan bahwa tingkat pengetahuan sebelum penerapan HACCP dikategorikan cukup baik.

Cukup baiknya rata-rata nilai pengetahuan sebelum penerapan $H A C C P$ tersebut, secara umum berhubungan dengan tingkat pendidikan subjek (tenaga penjamah makanan) di Instalasi Gizi RSUP Dr. Soedarso. Tenaga pengolah berpendidikan SMA/SMKK sebanyak $66,7 \%$ (4 orang), sedangkan tenaga yang bertugas membagi makanan diet dilakukan oleh Pembantu Ahli Gizi (Pendidikan D1 Gizi) sebanyak 33,3\% (2 orang). Dengan tingkat pendidikan tersebut maka tenaga pengolah di instalasi gizi telah mengetahui cara aman dan sehat dalam menjamah makanan.

Hal ini didukung oleh teori yang menyatakan bahwa peningkatan pengetahuan dapat diperoleh melalui proses belajar mengajar, baik melalui pendidikan formal maupun informal (21). Pendidikan formal kesehatan misalnya, melalui pengetahuan yang diperoleh saat mengikuti proses belajar di dalam kelas menggunakan kurikulum tertentu sedangkan informal dapat diperoleh dengan mengikuti pelatihan, penyuluhan, membaca standar operasional prosedur (SOP) tentang cara sehat dan aman mengolah makanan, dan lain-lain.

Sementara penelitian di Rumah Sakit Calabria, Italia menyebutkan bahwa terdapat kaitan antara tingginya tingkat pendidikan seorang staf pelayanan makanan di rumah sakit dengan pengetahuan cara aman dan sehat dalam proses pengolahan makanan. Selanjutnya staf pelayanan (penjamah) makanan yang tingkat pengetahuannya baik berhubungan dengan peningkatan implentasi sistem HACCP di rumah sakit (22).

Hasil analisis statistik menunjukkan adanya perbedaan yang bermakna pada tingkat pengetahuan penjamah makanan sebelum dan sesudah penerapan HACCP $(t=2,888, p=0,016)$. Penelitian ini sesuai dengan penelitian yang dilakukan di Instalasi Gizi Rumah Sakit (RS) Jantung Harapan Kita, hasilnya diketahui bahwa pengetahuan penjamah makanan mengalami peningkatan yang signifikan sesudah mengikuti pelatihan keamanan pangan/makanan (aplikasi HACCP) (23).

WHO dan Green menyebutkan bahwa tindakan atau praktik sehat (seperti praktik higiene sanitasi makanan/ keamanan pangan) salah satunya dipengaruhi oleh faktor predisposisi adalah tingkat pengetahuan (21). Pengetahuan merupakan domain yang sangat penting untuk menimbulkan tindakan atau praktik seseorang, karena perilaku yang didasari pengetahuan akan langgeng daripada tindakan yang tidak didasari oleh pengetahuan (24).

\section{Praktik higiene sanitasi makanan penjamah sebelum dan sesudah penerapan HACCP}

Berdasarkan Tabel 4 dapat diketahui rata-rata nilai praktik higiene sanitasi makanan, tentang cara sehat dan aman penjamah makanan mulai persiapan, pengolahan dan distribusi makanan, seperti mencuci tangan, menggunakan pakaian kerja dan tidak berbicara saat kerja, sebelum penerapan HACCP, yaitu 56,1. Nilai ini menggambarkan bahwa praktik higiene sanitasi makanan sebelum penerapan HACCP tergolong rendah, yaitu hanya 56,1. Setelah dilakukan penerapan HACCP rata-rata nilai praktik higiene sanitasi makanan mengalami peningkatan $(76,1)$.

Secara statistik dengan uji $t$ diketahui adanya perbedaan tingkat praktik higiene sanitasi makanan antara sebelum dengan setelah penerapan HACCP $(p=0,000)$. 
Hasil tersebut sejalan dengan penelitian di Calabria, Italia yang menunjukkan bahwa implementasi HACCP dan higiene makanan di rumah sakit dapat meningkatkan tingkat pengetahuan, sikap dan praktik atau perilaku pekerja (staf) pelayanan makanan (22).

Dengan demikian, aplikasi HACCP sangat diperlukan, seperti melalui kegiatan penyuluhan. Praktik langsung cara aman dan sehat pada proses persiapan bahan, pemberian petunjuk praktis cara pengolahan, pemantauan dan evaluasi yang dilakukan secara terus menerus, diharapkan dapat meningkatkan praktik atau perilaku higiene sanitasi makanan pasien di rumah sakit, seperti penggunaan pakaian kerja, pencucian tangan sebelum dan sesudah bekerja dan tidak berbicara saat melakukan pekerjaan. perlu dilakukan penguatan pengetahuan berupa pelatihan, supervisi, penyegaran melalui diskusi kelompok atau presentasi kasus dan lain-lain (24).

Melalui peningkatan perilaku atau praktik higiene sanitasi makanan bagi petugas masak/pengolah makanan, maka kualitas hasil olahan atau makanan yang siap didistribusikan kepada pasien menjadi baik atau jumlah angka kumannya menurun/berkurang. Secara statistik menunjukkan, bahwa semakin baik praktik higiene sanitasi petugas pengolahan, maka semakin menurun jumlah angka kuman pada makanan pasien $(r=0,504, p=0,048)$.

Keadaan ini seperti yang dijelaskan oleh hasil penelitian tentang keamanan pangan di rumah sakit tentang pengetahuan, sikap dan praktik staf keperawatan

Tabel 4. Praktik higiene sanitasi makanan penjamah sebelum dan sesudah penerapan HACCP

\begin{tabular}{ccccccccc}
\hline & \multicolumn{8}{c}{ Praktik higiene sanitasi makanan } \\
\cline { 2 - 9 } No & \multicolumn{7}{c}{ Sebelum penerapan HACCP } & \multicolumn{4}{c}{ Sesudah penerapan HACCP } \\
\cline { 2 - 9 } & $\mathbf{1}$ & $\mathbf{2}$ & $\mathbf{3}$ & Rata-rata & $\mathbf{1}$ & $\mathbf{2}$ & $\mathbf{3}$ & Rata-rata \\
\hline 1 & 55 & 60 & 58,3 & 75 & 75 & 75 & 75,0 \\
2 & 55 & 55 & 60 & 56,6 & 75 & 75 & 80 & 76,7 \\
3 & 60 & 55 & 60 & 58,3 & 75 & 75 & 80 & 76,7 \\
4 & 65 & 50 & 50 & 55,0 & 75 & 75 & 75 & 75,0 \\
5 & 50 & 60 & 55 & 55,0 & 75 & 75 & 75 & 75,0 \\
6 & 55 & 55 & 55 & 55,0 & 80 & 75 & 80 & 78,0 \\
Rata-rata & 56,7 & 55,8 & 55,8 & 56,1 & 75,8 & 75,8 & 76,7 & 76,1 \\
\hline
\end{tabular}

Keterangan:

$t=23,496$ dan ${ }^{*} p=0.000$

* Bermakna $(p<0,05$, uji $t)$

$1,2,3$ = Pengambilan sampel dengan interval minggu

Hubungan pengetahuan higiene sanitasi makanan, praktik higiene sanitasi makanan penjamah dan jumlah angka kuman pada makanan

Praktik higiene sanitasi makanan cenderung kurang baik pada saat tidak adanya atau kurangnya perhatian terhadap peningkatan pengetahuan. Peningkatan pengetahuan tersebut misalnya dengan memberikan pelatihan, penyuluhan atau melakukan evaluasi perbaikan secara rutin. Dengan melakukan kegiatan peningkatan pengetahuan cara aman dan sehat selama proses pengolahan makanan, maka praktik keamanan pangan juga mengalami peningkatan.

Hasil uji statistik menunjukkan adanya hubungan yang signifikan antara meningkatnya pengetahuan seseorang dengan bertambahnya praktik atau perilaku aman dan sehat dalam proses pengolahan makanan pasien $(r=0,748, p=$ 0.003 ). Melalui upaya perbaikan tingkat pengetahuan staf pengolahan (penjamah) makanan di instalasi gizi rumah sakit, maka diharapkan akan meningkatkan praktik higiene sanitasi makanan atau perilaku keamanan pangan.

Untuk mencegah terjadinya penurunan atau berkurangnya motivasi untuk praktik perilaku sehat maka pada dua Rumah Sakit di Sicilia, Italia bahwa pengetahuan yang baik akan memicu sikap positif dan perilaku aman dalam penanganan makanan pasien di rumah sakit (25). Praktik atau perilaku pejamah makanan terhadap keamanan pangan melalui implementasi sistem HACCP secara universal dan proaktif akan mencegah timbulnya bahaya mikrobiologis (mikroorganisme) penyebab foodborne disease.

\section{Higiene sanitasi lingkungan dapur sebelum dan sesudah penerapan HACCP}

Persyaratan kesehatan lingkungan tempat pengolahan makanan (dapur) diatur dengan Keputusan Menteri Keseharan (Kepmenkes RI), Nomor 715/Menkes/SK/ V/2003 tentang persyaratan higiene sanitasi jasaboga dan Kepmenkes RI Nomor 1204/Menkes/SK/X/2004, tentang persyaratan kesehatan lingkungan rumah sakit.

Hasil penilaian higiene sanitasi lingkungan sesudah penerapan HACCP mengalami peningkatan. Nilai rata-rata higiene sanitasi lingkungan dapur sebelum penerapan HACCP sebesar $61 \%$ dan setelah penerapan HACCP nilainya menjadi $68,7 \%$. 
Keadaan higiene sanitasi lingkungan dapur RSUP Dr. Soedarso Pontianak, terutama di tempat pengolahan makanan pasien masih ada yang belum memenuhi syarat, di antaranya penyediaan air minum/air bersih. Penyediaan air bersih secara kuantitas cukup tersedia berasal dari PDAM. Secara kualitas terutama mikrobiologis belum secara rutin dilakukan pemeriksaan jumlah angka kumannya. Penyediaan air bersih berperan penting dalam proses pengolahan makanan pasien. Untuk itu perlu penerapan persyaratan Kepmenkes tentang kesehatan lingkungan rumah sakit dan jasa boga tipe $B$, yaitu dengan melakukan pengambilan sampel untuk pemeriksaan mikrobiologis air mimum/bersih minimal dua kali dalam setahun.

Fasilitas lain sarana kesehatan lingkungan yang penting, yaitu tempat pembuangan limbah, baik cair maupun padat (sampah). Untuk sarana pembuangan limbah cair, terutama berasal dari aktifitas dapur, seperti berasal dari toilet/wc, kamar mandi dan limbah cair dari proses pengolahan makanan telah tersedia saluran pembuangan yang berfungsi dengan baik dan lancar. Saluran limbah cair dari aktifitas dapur dialirkan ke instalasi pengolahan limbah cair di rumah sakit. Fasilitas wc/toilet di dapur digabung dengan kamar mandi sebanyak dua buah. Jumlah tersebut belum menenuhi syarat. Menurut Kepmenkes tentang persyaratan higiene sanitasi jasaboga dan rumah sakit, rasio satu wc/toilet dan kamar mandi yaitu untuk 10 orang.

Pewadahan sampah di tempat pengolahan makanan pasien sebelum penerapan HACCP belum memenuhi syarat, yaitu hanya berupa keranjang plastik tidak kedap air dan tidak bertutup. Sampah langsung dibuang begitu keranjang penuh ke tempat pengumpulan sementara. Tetapi sampah sisa pengolahan sore berupa sisa nasi/bubur baru dibuang keesokan harinya, sehingga berada di ruang pengolahan lebih kurang 12 jam. Tempat pengumpulan sementara jaraknya terlalu dekat dengan dapur sekitar 5 meter, volumenya tidak dapat menampung sampah hasil kegiatan dapur, terbuka, berbau, banyak lalat. Sesudah penerapan HACCP tempat pewadahan sampah sudah memenuhi syarat tetapi tempat pengumpulan sementara masih seperti sebelumnya.

Menurut Kepmenkes Nomor 715/Menkes/SK/V/2003, untuk tempat sampah di ruang pengolahan sebaiknya terbuat dari bahan yang kedap air, tertutup, dilapisi kantong plastik dan mudah dibersihkan. Sampah harus sudah dibuang dalam waktu $1 \times 24$ jam. Untuk pengumpulan sampah sementara yang perlu diperhatikan yaitu volume tempatnya dapat menampung seluruh sampah hasil aktivitas dapur, dapat dilewati gerobak sampah, mudah dibersihkan, kedap air, tertutup dan tersedia kran pembersih. Sedangkan jaraknya dianjurkan sekitar $500 \mathrm{~m}$ dari dapur, tidak digunakan sebagai tempat perkembangbiakan vektor dan tikus, serta tidak diacak-acak anjing dan mudah diangkut oleh petugas sampah untuk dibuang ke tempat pembuangan akhir sampah (TPA) $(21,26)$.
Untuk tempat pencucian tangan belum tersedia. Tempat pencucian peralatan terbuat dari stainlessteel yang mudah dibersihkan. Namun belum dilengkapi kran air panas untuk keperluan proses pencucian lebih lanjut.

Menurut Kepmenkes Nomor 715/Menkes/SK/V/2003, tempat pencucian tangan hendaknya terpisah dengan tempat pencucian peralatan maupun makanan, jumlahnya disesuaikan dengan banyaknya karyawan dengan rasio satu untuk sepuluh orang (26).

Keadaan kesehatan lingkungan lantai yaitu bersih, terbuat dari bahan yang kuat dan kedap air. Lantai dapur dibersihkan dengan frekuensi dua kali sehari dengan menggunakan bahan pembersih yang mengandung desinfektan (lisol).

Dinding secara umum belum bersih, terdapat sisa minyak di dinding ruang pengolahan. Untuk itu menurut Kepmenkes Nomor 715/Menkes/SK/V/2003 bagian yang terkena percikan air/ minyak harus dilapisi dengan bahan yang mudah dibersihkan setinggi dua meter dari lantai (26).

Langit-langit dapur terbuat dari bahan yang kuat hanya saja warnanya nampak kusam, karena terakhir kali dicat sekitar tahun 2001. Menurut Kepmenkes Nomor 715/Menkes/SK/V/2003, langit-langit harus terbuat dari bahan yang kuat, permukaanya rata, tidak menyerap air dan berwarna terang (26).

Seluruh ruangan pengolahan terdapat ventilasi (penghawaan) dalam jumlah yang cukup dan mudah dibersihkan tetapi belum dilengkapi dengan kasa penahan lalat, tersedia sarana pembuangan asap, namun belum terdapat cerobong asap yang dilengkapi filter, kemampuan membuang asap dan bau-bauan dari proses pengolahan makanan belum sempurna dan ruangan masih terasa panas (belum ada alat pengatur suhu ruangan). Untuk itu diperlukan penambahan sarana pengatur suhu ruangan dan cerobong asap yang dilengkapi dengan filter serta kasa penahan lalat pada ventilasi.

Keadaan penerangan atau pencahayaan di ruangan dapur cukup memenuhi syarat untuk melakukan aktivitas pengolahan makanan. Pencahayaan bersumber dari sumber alami dan buatan.

\section{KESIMPULAN DAN SARAN}

Ada pengaruh penerapan HACCP terhadap menurunnya bahaya mikrobiologis (angka kuman) pada makanan pasien berbasis hewani. Ada perbedaan yang bermakna rata-rata jumlah angka kuman sebelum dan sesudah penerapan HACCP. Ada perbedaan yang bermakna ratarata nilai pengetahuan higiene sanitasi makanan sebelum dan sesudah penerapan HACCP. Ada perbedaan yang bermakna rata-rata nilai praktik higiene sanitasi makanan sebelum dan sesudah penerapan HACCP. Nilai higiene sanitasi lingkungan tempat pengolahan masih di bawah 
nilai stándar yang disyaratkan Kepmenkes RI tentang persyaratan higiene sanitasi jasa boga tipe B.

Berdasarkan hasil penelitian ini, maka disarankan kepada berbagai pihak untuk melaksanakan hal-hal sebagai berikut:

Instalasi Gizi. Perlunya Membuat program kerja untuk pelatihan HACCP bagi karyawan secara berkala, pemeriksaan kesehatan secara rutin, pemeriksaan angka kuman pada makanan dan peralatan, monitoring dan evaluasi secara terus menerus terhadap cara kerja yang sehat dan aman dalam proses pengolahan makanan. Perlunya meningkatkan kepatuhan terhadap spesifikasi bahan makanan pada saat penerimaan. Perlunya membuat program kerja untuk melengkapi sarana penunjang semua kegiatan penyelenggaraan makanan seperti tempat penyimpanan peralatan, meja persiapan, meja pengolahan, tempat pencucian tangan, penyediaan air panas dan diterjen yang mengandung bakterisida untuk pencucian peralatan.

Manajemen Rumah Sakit. Perlunya melakukan perencanaan, pengorganisasian, pengarahan dan evaluasi terhadap peningkatan kegiatan cara sehat dan aman dalam proses pengolahan makanan pasien, memberi dukungan kepada instalasi gizi untuk menerapkan prinsip HACCP secara bertahap. Perlunya meningkatkan implementasi higiene sanitasi lingkungan rumah sakit dengan melibatkan instalasi terkait (instalasi sanitasi lingkungan rumah sakit), serta melengkapi sarana yang dapat menunjang kegiatan tersebut.

Petugas Masak (Penjamah Makanan). Perlunya meningkatkan pengetahuan dan perilaku/praktik higiene sanitasi makanan mulai tahap persiapan, pengolahan maupun distribusi melalui pelatihan-pelatihan. Selain pembuangan sampah dilakukan tiap dua jam sekali untuk menghindari perkembangbiakan lalat.

\section{UCAPAN TERIMA KASIH}

Penelitian ini terlaksana berkat dukungan dari RSUD Dr. Soedarso Pontianak. Pada kesempatan ini kami mengucapkan terima kasih kepada Direktur RSUD Dr. Soedarso Pontianak atas izin dan dukungan sehingga penelitian dapat terlaksana.

Ucapan terima kasih juga kami sampaikan kepada semua karyawan instalasi gizi, teman-teman dari Politeknik Kesehatan Pontianak dan subjek yang telah banyak membantu dalam penelitian ini.

\section{RUJUKAN}

1. Departemen Kesehatan RI. Pedoman Pelayanan Gizi Rumah Sakit (PGRS): Dirjen Binkesmas; 2005.

2. Iskak R. Infeksi Nosokomial dan Staphylococcus epidermidis. Republika [serial online] 2006 [cited 2007
Nov 4]. Avalaible from: www.republika.co.id.

3. Giroult E, Pruss A, Rushbrook P. Safe of Waste from Health - Care Activities. Geneva: World Health Organizaton (WHO); 1999.

4. Departemen Kesehatan. Hazard Analysis Critical Control Point (HACCP), Analisis Bahaya Titik Kendali Kritis (ABTKK). Jakarta: Dirjen PPM \& PL; 2000.

5. Hasyim H. Manajemen Hyperkes dan Keselamatan Kerja di Rumah Sakit (Tinjauan Kegiatan Keselamatan dan Kesehatan Kerja di Institusi Sarana Kesehatan). Jurnal JMPK Vol. 08/No.02 [serial online] 2005 [cited 2007 Jun 15]. Avalaible from: http://www. JMPK. Online.net.

6. RSUD Dr. Soedarso. Medical Record Rumah Sakit Umum Daerah, Pontianak; 2005.

7. Departemen Kesehatan. Bakteri Pencemar Makanan dan Penyakit Bawaan Makanan. Dirjen PPM \& PL. Jakarta: Depkes RI; 2000.

8. Afriani R. Hubungan Angka Kuman Peralatan Makan dengan Angka Kuman pada Makan Siang Pasien di Ruang Isolasi dalam Menular Rumah Sakit Umum (RSUD) Dokter Soedarso Pontianak. Laporan Riset Tenaga kesehatan (Risnakes). /Pontianak: Politeknik Kesehatan Depkes; 2004.

9. Krisnamurni,S. Penerapan Keamanan Pangan Pada Penyelenggaraan Makanan di Rumah Sakit, Makalah Disampaikan pada pertemuan ilmiah nasional Asosiasi Dietisien Indonesia ke III di Semarang, 19 - 21 Juli 2007.

10. Sudarmadji. Analisis Bahaya dan Pengendalian Titik Kritis (Hazard Analyis Critical Control Point, Jurnal Kesehatan Lingkungan 2005: Vol. 1 No.2. p 183-90.

11. Maddox Ian S. The Hazard Analysis Critical Control Point System (HACCP), Practical Sanitation in the Food Industri. New Zealand: Gordon and Breach Science Publishers; 1994.

12. Standar Nasional Indonesia (SNI 01-4852). Sistem Analisa Bahaya dan Pengendalian Titik Kritis (HACCP) serta Pedoman Penerapannya. Jakarta: Badan Standarisasi Nasional (BSN); 1998.

13. Departemen Kesehatan RI. Pedoman Pelayanan Gizi Rumah Sakit. Jakarta: Dirjen Binkesmas Depkes RI; 2005.

14. Murti B. Prinsip dan Metode Riset Epidemiologi. Yogyakarta: Gadjah Mada University Press; 1997.

15. Sugiyono. Statistika Untuk Penelitian. Bandung: Alfabeta; 2007.

16. Azwar A, Prihartono J. Metodologi Penelitian Kedokteran dan Kesehatan Masyarakat. Jakarta: Binarupa Aksara; 2003.

17. Estremera, E. (2003) The Aplication of Hazard Analysis and Critical Control Points (HACCP) in the Preparation of Blenderized Feeding Formula in a Hospital Food Service Institution, Diliman, Quezon City, Philippines. 
[serial online] 2003 [cited 2007 Dec 29]. Avalaible from http:// www.fr.dost.gov.ph//files.

18. Arias., Monge. dan Chavez. (2003) Microbiological Contaminaton of Enteral Feeding Solutions Used in Costa Rican Hospital, PubMed - Indexed for Medline, 2003 Sep; 53 (3): 277-81 [serial online] 2003 [cited 2007 Dec 29]. Avalaible from: http://www.ncbi.nih.gov/ pubmed (Diakses, 29 Desember 2007).

19. Oliveira MR, Batista CRV, Aidoo KE. (2001) Application of Hazard Analysis Critical Control Point System to Enteral Tube Feeding in Endereao do Hospital Governador Celso Ramos, Rua Irma Benvarda, Florionopolis, Santa, Catarina, Brasil, PubMed-indexed for Medline, 2001 Oct: 14 (5): 397-403 [serial online] 2001 [cited 2007 Dec 29]. Avalaible from: http://www. ncbi.nlm.nih.gov/sites/entrez.

20. Departmen Kesehatan RI. Kursus Hygiene Sanitasi Makanan dan Minuman. Jakarta: Dirjen PPM dan PL; 2004.

21. Notoatmodjo S. Promosi Kesehatan dan Ilmu Perilaku. Jakarta: Rineka Cipta; 2007.
22. Angelillo I, Vigiani N, Greco R dan Rito D. HACCP and Food Hygiene in Hospital: Knowledge, Attitudes, and Practices of Food Service Staff in Calabria, Italy [serial online] 2001 [cited 2001 Aug 02]. Avalaible from: http:// www.Journal. Uchicago.edu. pages 363-9. vol. 22.

23. Prasetyaningsih A, Sudargo T, Susilo J. Pengetahuan, Sikap dan Ketrampilan Penjamah Makanan yang Diberi Pelatihan Keamanan Pangan di Instalasi Gizi RS Jantung Harapan Kita. Jurnal Gizi Klinik Indonesia 2005: 2 (2): 68-74.

24. Walgito B,. Pengantar Psikologi Umum. Yogyakarta: Andi Offset; 1997.

25. Buccheri C, Casuccio A, Giammanco S, Guardia M, dan Mammina C. Food Safety in Hospital: Knowledge, Attitudes and Practices of Nursing Staff of two Hospitals in Sicily, Italy, BMC Health Service Research [serial online] 2007 [cited $2007 \mathrm{Dec} 30$ ]. Avalaible from: http://www.biomedcentral.com/1472-6963/7/45.

26. Departemen Kesehatan RI. Keputusan Menteri Kesehatan (Kepmenkes) No.715/Menkes/SK/ V/2003 tentang Persyaratan Hygiene Sanitasi Jasaboga; 2004. 